\title{
Collective action problems and the role of South African business in national and regional accords
}

\author{
Nicoli Nattrass \\ Department of Economics, University of Cape Town, Private Bag, Rondebosch, 7701 Republic of South Africa \\ Nattrass@socsa.uct.ac.za
}

Received July 1997

\begin{abstract}
This article examines some of the collective action problems which beset South African business in national and regional accords. The first part concludes that incomes policy type accords at national level are unlikely to be successful in South Africa. The main part of the article considers accords at subnational level where conflicts of interest are more easily (but not entirely) resolved. This is done by means of two case studies of business acting collectively to promote regional or local development. The first looks at the role of organized business in the Eastern Cape Socio-Economic Consultative Council (ECSECC). It is suggested that the geographical divide between the various business organizations undermines the potential for collective action. The second describes the more successful local housing accord which was negotiated in Port Elizabeth.
\end{abstract}

Over the past eight years there has been a burgeoning of tripartite forums and institutions in South Africa (Sellars, 1996: 17-20). In both discourse and institutional design, corporatism has become an important feature of South Africa's fledgling democracy. (See Schreiner, 1994; Maree, 1994; Goldberg, 1994; and Sellars, 1996 for a discussion of the meaning of corporatism and its manifestation in South Africa.) First, the old National Manpower Commission (NMC) was restructured to include representatives of organized business and labour as well as government. Then, following two general strikes and a threatened income-tax boycott by the Congress of South African Trade Unions (COSATU), the National Party government acceded to labour's demands and set up the tripartite National Economic Forum (NEF) in 1992. This inspired the creation of a range of more narrowly focussed national tripartite forums (such as the National Housing Forum and the National Electricity Forum), and various regional development forums at a subnational level.

After the transition to democracy, some consolidation took place when the NMC and NEF were merged to form the National Economic Development and Labour Council (NEDLAC). Whereas the NEF was weakened by its status as a mere talkshop, the 1995 NEDLAC Act requires that the government table all significant social and economic policies in NEDLAC before introducing them in parliament. NEDLAC's major success to date has been the negotiation of the $1995 \mathrm{La}$ bour Relations Act.

According to recent policy documents, much greater things are expected of the growing corporatist current. The Labour Market Commission report (LMC, 1996) goes as far as suggesting that a national social accord could be struck in NEDLAC over wages, prices and investment (a type of incomes policy), and that regional social accords could help cushion the effects of structural adjustment. Likewise, the recent ILO Review supports the idea of social accord processes - particularty at regional level (Standing et al., 1996: 494-500). A gesture in the direction of both national and regional accords can also be found in the government's macroeconomic strategy document (Ministry of Finance, 1996), although the nature and content of such accords is left rather vague.
However, it is questionable whether organized labour and business are really in a position to start negotiating ambitious accords at national or regional levels. It is a moot point whether the 'social partners' are sufficiently well and comprehensively organized that they can articulate a coherent position and deliver their membership in support of such accords.

The literature on corporatism in South Africa is surprising silent on these questions. Apart from Sellar's (1996) innovative application of public choice theory to NEDLAC, no specific work has been done on the collective action problems which constrain the scope for tripartite agreements. While there are a few good reflective papers about labour's capacity to negotiate and deliver (Baskin, 1993; Naledi, 1994; Sellars, 1996), there is very little about the organizational strengths and weaknesses of South African business. Apart from Douwes Dekker (1988; 1990), and Nattrass (1997) very little recent research work has been dedicated to organized business in South Africa.

This article examines some of the collective action problems which beset South African business in social accord processes at national and regional levels. Collective action problems arise when there are benefits to co-operation at the same time as it is in the interests of individuals to act in ways which undermine the collective interest. The first section briefly considers collective action problems at national level and concludes that incomes policy type accords are unlikely to be negotiated successfully in South Africa. The main part of the article then considers accords at subnational level where conflicts of interest and collective action problems ought to be more easily (but not entirely) resolved. This proposition is explored by means of two case studies from the Eastern Cape.

\section{Collective action problems at national level}

According to Olson (1965; 1986), the larger and more 'encompassing' an organization, the more likely it is to pursue its interests in socially beneficial ways. Smaller, narrower organizations, by contrast, may prefer to act as 'redistributive coalitions' and pursue their interests at the expense of society. Put differently, encompassing organizations stand to gain 
more by acting to increase the size of the pie, whereas redistributive coalitions gain more by increasing their share of it.

This insight is applicable when exploring the ways in which organized labour and business might behave at national and sectoral levels. According to Calmfors \& Driffill (1988), centralized wage bargaining arrangements are less likely to be associated with inflation than systems of industry-level bargaining. The assumption is that negotiators at central level are forced to confront (and are in a position to estimate) the macroeconomic consequences of their wage settlements. Thus when national business and labour organizations are sufficiently encompassing, they are more likely to act in macroeconomically beneficial ways when bargaining wages in central forums. (Scandinavia during the heyday of social democracy is usually regarded as the classic example [Henley \& Tsakalotos, 1993]). By contrast, parties to industry-level bargains tend to have less information about wage deals in other industries, and hence are often not in a position to consider the macroeconomic consequences of their (or other industry's) wage settlements. Rather, industrial unions have an incentive to negotiate a margin above their desired real wage - and thus contribute to inflationary pressures.

Business is also likely to act as a redistributive coalition when organized along sectoral lines. For example, businesses oriented towards the domestic market (and relying on tariff protection) are likely to lobby against trade liberalization and other structural adjustment policies which (potentially) support more rapid and sustained growth elsewhere in the economy. This danger is even greater when business is organized along both sectoral and regional lines' as they are well placed to lobby for the introduction (or maintenance) of policies such as regionally specific investment and transport subsidies. $^{2}$

National-level business organizations can avoid the dangers of redistributive coalitions - as long as they are sufficiently representative to be 'encompassing'. However, as Olson points out, even encompassing organizations such as centralized employers federations experience collective action problems. Their component branches still have

'an incentive to push for the interests of their own branch, even when this is not in the interests of clients of the encompassing organization as a whole' (1986: 184).

He suggests that unless organizations can provide 'selective incentives' which induce membership compliance through positive or negative sanctions, the organizational dynamics of encompassing organizations under corporatist arrangements are likely to be unstable.

The above analysis poses two questions for organized South African business at national level: is the national peak business organization, Business South Africa (BSA), sufficiently encompassing that socially optimal policies are pursued; and can BSA ensure that its members actually comply with nationally negotiated decisions?

As regards the first question, some doubts have been raised about the representivity of BSA, especially when it comes to small and black businesses (Nattrass, 1997). Historically rooted language and sectoral divisions and the dominant role played by large corporations (particularly in the mining industry) are further causes for concern. There is a danger that in negotiating on the behalf of business in general, BSA may in fact pursue the interests of larger businesses (particularly those in the mining and metals industries) and neglect those of smaller industries in weaker sectors such as clothing and textiles. BSA does not appear to be sufficiently encompassing to be able to negotiate a structural adjustment policy or an industrial strategy which would be acceptable to the business community as a whole.

As regards the second question, it is important to remember that BSA is a loose, consensus-driven body with no capacity (or intention) to discipline errant members. Similarly, the trade and employer associations which belong to BSA have little capacity to ensure compliance. South African employers associations rely on the carrot of services rather than the stick of sanctions. This is the case in most other countries (Windmuller, 1984: 20). BSA is thus likely to be able to negotiate only those agreements which are broad and general, and which require no disciplining of members to succeed. This contrasts sharply with the Swedish centralized employers association, the Svenska Arbetgivareforeningen (SAF) which until 1982 required that no affiliate could enter into a collective agreement without its formal approval (Tolliday \& Zeitlin, 1991: 302). Those who failed to comply with this rule suffered social sanctions and loss of access to strike insurance funds and information.

These institutional limitations place constraints on the range of feasible bargains which could be negotiated in NEDLAC. It certainly raises some hard questions about the possibility of an incomes policy type accord being bargained in NEDLAC. In this regard, a recent NEDLAC Discussion Document talks optimistically of

'developing an agreed national framework for collective bargaining that promotes certain outcomes in industry level negotiations, or at the minimum provides a "menu" of options for negotiations at industry level' (NEDLAC, 1995: 6).

Similar sentiments are expressed in the Labour Market Commission Report (LMC, 1996: chapter 10). However, in light of the absence of any mechanisms to ensure that either employer's associations or trade unions actually bargain within a nationally negotiated menu, such proposals appear rather whimsical.

\section{Collective action problems at regional level}

Partly in recognition of these limitations, the recent Labour Market Commission Report (LMC, 1996) and ILO Review (Standing et al., 1996) expressed support for a range of social accord processes rather than a single dominant national incomes policy. The emerging vision is that NEDLAC should provide some kind of national framework for sectoral accords (between industrial unions and employers associations in industrial councils) and regional accords (between labour, business, regional government and community organizations). The remainder of this article explores the role of business in regional accord processes through two case studies in the Eastern Cape.

One would expect collective action problems amongst business to be less onerous at regional than at national level. Van Waarden argues in his comparative study that as regional 
associations are generally smaller in size and spatially closer to their members than national associations,

'they will be more homogenous, so that individual members may recognise more easily their own particularistic interests in the policies of the association and may be willing to contribute resources to the collective cause' (1989: 16).

However, even where businesses in specific regions recognize a common interest and agree on the need for social and economic development, this does not mean that each business will act accordingly, for example by increasing their social responsibility investment projects. Collective action problems at all levels tend to result in the underprovision of non-profit related activities. ${ }^{3}$

To return to Olson's framework once again, businesses may appreciate the importance of regional development and agree on goals set in support of it, but still find it rational to freeride on the developmental activities of other firms. According to Oison, such collective action problems result in public goods being underprovided by groups other than 'privileged' or 'intermediate' groups. A 'privileged' group is one in which at least one of the members has an incentive to provide the public good, even if they have to bear the full burden of the costs (Olson, 1965: 50). A large, dominant firm in a particular area may be an example. An 'intermediate' group is one in which no single member has an incentive to provide the public good, but which has sufficiently few members that mutual monitoring is possible. Quite a few local business organizations may fall into this group, depending on the social pressure (or in Olson's terminology, the 'social incentives') which can be brought to bear on members not to free-ride.

These hypotheses are explored below by means of two case studies of South African business acting collectively to promote regional or local development. The first looks at the role of organized business in the Eastern Cape Socio-Economic Consultative Council (ECSECC). It is suggested that geographical divisions between the various business organizations undermine the potential for collective action. The second describes the housing accord which was negotiated in the metropolitan area of Port Elizabeth and suggests that the incentive structure is more conducive to success.

\section{Methodology}

Twenty-two unstructured, open-ended yet purposive interviews were conducted between April and October 1996 with representatives of business, labour and the NGO community in East London and Port Elizabeth. The major players (identified from newspaper reports) were interviewed first. On the basis of these interviews, other players were identified and then interviewed (as in a snow-ball sample). Many of those interviewed did not wish to be quoted directly.

\section{Business in the Eastern Cape Socio-Economic Con- sultative Council}

The Eastern Cape has the second lowest per capita income, the lowest life expectancy and the highest infant mortality of South Africa's nine provinces (DBSA, 1994). According to the SALDRU survey, it has the highest unemployment rate (47.3\%) in the country (Standing et al., 1996: 110). To make matters worse, unemployment could rise further over the next few years as the effects of South Africa's tariff reduction programme are felt by the Eastern Cape's clothing, textile and automobile producers. Despite the dire employment situation, trade unionism is strong and militant in the Eastern Cape. For example, when organized labour called a national stayaway in April 1996 in support of its demand that the constitution not entrench the right to lock-out, the stayaway was highest in the Eastern Cape (an estimated $90 \%$ of workers stayed away from work). This in part reflects the history of the Eastern Cape as an important centre of resistance against apartheid.

The Eastern Cape's bleak economic outlook is exacerbated by the crisis of regional and local government in the province. The Eastern Cape was constructed out of the old (white) Eastern Cape province and the old 'homeland' governments of the Ciskei and the Transkei. The provincial capital is now located in the old Ciskei capital (Bisho), whereas the economic base of the province is located in the old white capital of Port Elizabeth (about three hours' drive away) which is responsible for an estimated $58 \%$ of gross geographic product. Largely as a result of the difficulties involved in amalgamating three government bureaucracies, many problems remain regarding the efficiency and effectiveness of government. ${ }^{4}$ Local government in the old Transkei has all but collapsed.

According to all the Eastern Cape representatives of business organizations that were interviewed as part of this study, the development crisis faced by the Eastern Cape is one of government, investment and labour militancy. A recurring theme amongst business people is that special dispensations should be granted to the Eastern Cape by national government - such as more flexible wage determination systems, possible export processing zones and investment incentives. Other proposals include injecting regional and local government with expertise from the private sector (more about this below), developing a coherent economic plan, and marketing the Eastern Cape to potential investors.

There appears to be a great deal of frustration on the part of business people towards national institutions such as industrial councils (some of which set wages across the entire country) and NEDLAC. According to one business representative, NEDLAC consists of 'big business and big labour looking after Gauteng'. According to another, it was an 'irrelevant bureaucratic disaster specializing in wasting time and producing kilograms of paper'. There is a clear perception amongst Eastern Cape business representatives that accords between the social partners are more meaningful and desirable at regional rather than national level. However, as the brief history of ECSECC below shows, unilateral and unaccountable action on the part of business in the Transkei is causing tension between the 'social partners', and on-going geographical rivalry is undermining collective action on the part of business.

The Eastern Cape has a fairly well established tradition of consultation between business, labour and community structures over development issues. During the late 1980s and early 1990s, the Consultative Business Movement (CBM) engaged in a process of 'bilateral negotiations' with extra-parliamentary activists in the United Democratic Front and the Mass Democratic Movement. These negotiations spawned two multilateral development conferences in 1990 and 1991. The trade union movement, however, was suspicious about the CBM's dual role of facilitator and representative of 
business. After further negotiations, the CBM withdrew and a Regional Economic Development Forum was set up involving all the major stakeholders. According to Kevin Wakeford of the Port Elizabeth Regional Chamber of Commerce and Industry (PERCCI), the forum created the groundwork and impetus for ECSECC (interview, 26/4/96).

In 1995 a summit on Eastern Cape Reconstruction and Growth was held at which all the major players in business, labour and the state were represented. Participants committed themselves to developing co-operation amongst all the stakeholders and working towards 'social and industrial stability' and an 'economic environment conducive to job creation and growth in the Eastern Cape' (Framework Agreement, April, 1995). It was decided that a 'consultative council inclusive of all stakeholders should be established to facilitate discussions, strategies and develop policies for implementation' (Framework Agreement, April, 1995).

This lead to the setting up of ECSECC as a government funded non-government body. It was launched on 31 July 1995, and in early 1996, Mcebisi Jonas (from the NGO Coalition) was appointed Executive Director. ECSECC is modelled loosely on NEDLAC and has four broad constituencies: labour (represented by COSATU), business, government and the non-governmental organization sector (represented by the Eastern Cape NGO Coalition). According to the Founding Document, the principal objective is

'to advise and assist the provincial government to achieve an integrated development strategy for the province and its constituent regions, in order to address the economic development of the province in terms of the RDP, and in particular the needs of the deprived communities and underdeveloped areas'.

One of Jonas' first initiatives was to arrange a 'strategic planning session' on regional development issues. This resulted in the tabling of businesses 'short-term demands' (which included development zones, exemptions from the Labour Relations Act, provincial investment incentives and less labour militancy). The strategic planning session also stressed the need for capacity building so that the participants in ECSECC could make better inputs. Jonas is particularly concerned to improve the capacity of COSATU to make strategic interventions in ECSECC (interviewed, 26/4/96).

The business caucus on ECSECC is known as the Eastern Cape Co-ordinating Committee (ECCC) and is chaired by Ian Russel of Mercedes Benz (East London). The ECCC includes representatives from PERCCI, the Border Chamber of Business, the Afrikaanse Handelsinstituut, the National African Federated Chambers of Commerce, and the Foundation for African Business and Consumer Services. The latter two organizations represent black business.

The ECCC is a powerful grouping whose existence precedes that of ECSECC. In 1994, for example, it produced an economic strategy document which served as a major impetus for the 1995 summit discussed above. ECCC's most important, yet controversial, initiative is the Project Management Task Team (PMTT) which mobilizes private sector resources (largely in the form of seconded advisory manpower) to help re-establish local government infrastructure and services in the old Transkei. The PMTT was set up under the auspices of the Reconstruction and Development Programme (RDP), but run mainly by business.

Once ECSECC came into being, the PMTT was placed within its ambit on the expectation that labour and the NGO community would become involved. The NGO Coalition and COSATU, however, regard such involvement as tokenistic and are deeply suspicious of the consultants who drive the PMTT. According to Russel Grinker (from the NGO Coalition and ECSECC), the PMTT was 'run past ECSECC's nose', and that there is a great deal of suspicion about the way in which it is run by a construction company projects manager who apparently has 'divided the Transkei between different consortia of consultants' and lives with his team in the old ruler of Transkei, Kaiser Matanzima's palace (interview, 10/10/96). Grinker's concerns were also echoed by Wakeford (PERCCI) who argued that the private sector should not get involved in doing the job of government because the tension between public service and private gain all too easily leads to corruption.

The NGO Coalition and COSATU went as far as to conduct an independent study which concluded that the PMTT failed to develop the capacity of provincial line departments, has not promoted community-driven development initiatives and has instead opted for a consultant-driven process dominated by aging white males (Eastern Cape NGO Coalition, 1996). This on-going suspicion about the PMTT, coupled with the manifest failure of ECSECC to resolve the tension internally, does not reflect well on ECSECC's ability to foster constructive relationships between the social partners.

Another on-going source of strife in ECSECC is the business demand that organized labour puts the regional labour market higher up their agenda than national trade union politics. This issue came to a head in March when COSATU called for a national stayaway on 30/3/96. The regional COSATU union structures immediately pledged their support. Incensed that organized labour had not been prepared to discuss the stayaway in ECSECC - and by the regional government stating that COSATU had a right to participate in the stayaway - the entire business caucus pulled out of ECSECC on 24/4/96. According to Peter Miles, business decided to suspend its participation in ECSECC until it got a commitment from the regional government and labour to prioritize the region and take regional issues seriously'. Trevor Campbell (Foundation for African Business and Consumer Services) expressed similar sentiments, charging that the COSATU in the Eastern Cape was 'remote-controlled by national' (interview, 10/10/96). As of early 1997, business was still formally 'outside' of ECSECC, but was nevertheless still sending 'observers' to meetings.

There is clearly a gulf between what business expects labour to bring to the bargaining table in ECSECC, and what labour is prepared to do. According to regional COSATU representatives, they are not prepared to allow ECSECC to undermine national structures (such as NEDLAC) or to undermine national industrial wage determination mechanisms (interview with A. Mtsi, P. Ntsangani \& S. Nondwangu, 26/4/ 96). They believe that Eastern Cape employers already obtain an unacceptably large number of exemptions from national wage agreements. They are also opposed to export processing or development zones if these contain lower labour standards. 
Although Monde Tom (the Permanent Secretary for Economic Affairs in the Eastern Cape) claimed that trade union militancy had declined as a result of setting up ECSECC (interview, 25/4/96), this was denied by COSATU.

According to COSATU (Eastern Cape office), their main purpose for participating in ECSECC is to address the inadequacy of government in terms of its delivery and strategic direction. Russel Grinker adds that a further motivation of COSATU and the NGO sector for participating in ECSECC is to balance the power of business when it comes to influencing government policies and actions. COSATU and the NGO Coalition are concerned about the lack of an effective strategy to address poverty, and the inadequate institutional basis for participative economic growth. Business (particularly in the East London and border region) is concerned about the collapse of local government services.

It is in these respects that the ECSECC operational teams appears to have made some headway. According to Grinker, ECSECC projects include: a pilot project to provide performance evaluations within government structures; mobilizing local expertise to prevent wasting government money on outside consultants; helping government co-ordinate its various strategic planning initiatives; and helping government develop the institutions required by the national Development Facilitation Act (that is, setting up tribunals to replace the old planning infrastructure).

There is, however, a widespread perception amongst business representatives that ECSECC has 'done nothing' and that good suggestions get lost in bureaucracy, and that attending meetings is a 'waste of time'. Given that ECSECC appears to have helped the provincial government in its attempts to strategize and implement development, such complaints are excessive - particularly given that the main stated purpose was to help government. Why then is business disgruntled? The root of the problem probably lies with collective action problems in the business community.

\section{Collective action problems amongst business in EC- SECC}

The major problem faced by organized business on ECSECC is overcoming the regional divide. All business has an interest in development proceedings in the Eastern Cape, however there is competition between Port Elizabeth on the one hand, and East London and the border region on the other, over the geographical location of that development. Business representatives in East London stress the need for additional government resources to address the slow growth and widespread poverty in the area - most of which is concentrated in the old bantustans. Business representatives in Port Elizabeth, by contrast, argue that Port Elizabeth is the natural centre for industrial development, and that the East London area should concentrate on tourism. The current competition between East London and Port Elizabeth over a proposed industrial harbour site, is exacerbating the divide. In this respect, organized Eastern Cape business is a very fragile alliance between two competing redistributive coalitions.

Likewise, although all business has an interest in the efficient functioning of the provincial government, this interest is not felt equally between the subregions. While the problems of local government in the old Transkei and Ciskei are of con- cern to border business, they are of far less concern to Port Elizabeth business. It is not surprising that the PMTT initiative to get local government back on its feet in the old Transkei and Ciskei is centred around Mercedes Benz in East London. Note that the existence of this powerful company makes organized business in the East London or border region a 'privileged group' in the sense that Mercedes Benz often acts on the part of business - even when it bears all the costs of doing so. Atlantis Diesel Engine plays a similar role in Atlantis in the Western Cape (Nattrass, 1996).

To the extent that the development priorities of the Eastern Cape government are directed towards the poor border region, these are of relatively little concern to Port Elizabeth business. Given that Port Elizabeth business (being the powerhouse of the region) has good relations with key economic players in government (such as Smuts Ngonyame, MEC for Economic Affairs), there is a clear incentive for Port Elizabeth business to act unilaterally, rather than through ECSECC, in its relations with government.

To overcome this regional or economic divide which underpins the fragility of business unity in the Eastern Cape, the business caucus on ECSECC has found it necessary to foster unity through focussing on areas of concern to all business namely labour. This may in part explain why business chose to take such a fighting stance over COSATU's participation in the one-day stayaway in April - a battle which business must have known it was going to lose given COSATU's militant history in the region." It may also explain why business chose to elevate labour issues above all others - to the extent that business pulled out of formal participation in ECSECC.

Given the fractures within the Eastern Cape business community, it is quite possible that the labour issue was a convenient excuse to pull out of (or at least limit their participation in) ECSECC. The collective action problems appear very real at regional level, and unless these can be overcome, ECSECC is unlikely to become anything more than a talkshop and a forum for East London-based business and NGO groupings to influence government. Port Elizabeth business will influence regional government directly on selected issues, and as argued below, will put its energies into local accords which have already started delivering concrete benefits.

\section{Accords in Port Elizabeth}

During the second half of 1996, three major social accords came into being in Port Elizabeth. The first, which is known as the Port Elizabeth Initiative for the Employed, was facilitated by Roger Matlock of Delta Foundation. Matlock managed to bring organized labour (COSATU mainly in the form of the National Union of Metal Workers of South Africa [NUMSA]), business (PERCCI) and local government together in order to do something about the 8000 'underhoused' factory workers in Port Elizaheth. The result was a social accord in which all the major stakeholders agreed to participate. Organized labour agreed to help define credit criteria and engage in an extensive consultation and education process amongst workers. Organized labour and business agreed to irrevocable payroll deductions for mortgage lenders. The local government agreed to allocate four cells of land within 15 minutes from workplaces for 250 houses each at Rl a square meter, and to provide adequate rebates for developers 
(regarding the provision of certain infrastructure). A R10 million housing subsidy was negotiated with the Provincial Housing Board.

The initiative was implemented through the work of a team consisting of representatives of business, labour and government. Community organizations (in the form of the South African National Civics organization) were also represented, but more as observers owing to the 'greenfields' nature of the development. The stakeholders examined various tenders for the construction of houses and eventually awarded one land cell to the established company Stocks and Stocks, and the other three to NEWCO (a new black-owned housing company). Workers can choose housing designs ranging from R25 000 to R65 000. The scheme essentially gives the workers free sites. Show houses were completed by the end of October 1996.

The second accord, known as 'Managing Masakane' involves labour agreeing to payroll deductions for municipal services. This is a major breakthrough in the light of $\mathrm{CO}$ SATU unions' persistent opposition to payroll deductions. The idea of payroll deductions for municipal services was actually raised in ECSECC, but rejected by organized labour. In the case of Port Elizabeth, however, not only did organized labour agree to payroll deductions, but the initiative came from COSATU which approached the PERCCI for support. According to a PERCCI circular (23/9/96), COSATU approached the chamber:

'out of concern that development projects were not being initiated by the City Council in marginalised areas due to fiscal constraints caused by arrears and non-payment problems. COSATU indicated that its membership were willing to have their municipal services payments deducted from their salaries and wages and that this would contribute significantly to boosting the city's fiscus. They however, expressed concern that certain employers were not willing to assist in this regard. COSATU also indicated that they would begin a massive campaign amongst their members to support this issue'.

PERCCI supported the initiative as it promoted 'creditworthiness', broadened the tax base and supported sustainable development. As their part of the bargain, employers were encouraged by PERCCI to assist by allowing COSATU shop stewards to conduct briefings, and to help workers calculate affordable instalments and sign payroll instruction or consent forms.

The third initiative is centred around the proposed development of Coega into an industrial zone and harbour. A planning company was set up to plan for an industrial development zone by March 1997. The initiative was divided into two sets of participants: the 'enablers' (organized business, organized labour, the Port Elizabeth City Council, the provincial government and the Department of Trade and Industry), and the 'risktakers' (five major companies, the Industrial Development Corporation and the Development Bank of Southern Africa).

All participants contribute finances and manpower. The aim is to promote development in the region by encouraging substantial industrial investment to Coega - a coastal region 20 kilometres from Port Elizabeth. As noted earlier, it is this competition over industrial development which has driven a major wedge between organized business in the Eastern Cape.?

\section{Collective action in Port Elizabeth}

In the case of the Eastern Cape, collective action at the municipal or local level has obvious advantages over that at regional level. Firstly, the issues are more focussed and all parties have a tangible interest in development occurring in the area. This allows for greater unity within the business community, and between business, labour and the local government.

However, business in the Port Elizabeth area still has to overcome the standard problem of collective action, that is free-riding. For example, in the case of the payment of municipal services initiative, it may well be in the interests of an individual firm not to participate if the owner fears that a payroll deduction may be passed on to him in the form of increased wage demands (in order to maintain take-home pay).

Such free-riding can be overcome through organizational and social pressure. Firstly, PERCCI can place gentle pressure on its membership to participate through appeals. Secondly, and probably more importantly, business people can place pressure on one another during the normal course of social interaction. In this sense, organized business in Port Elizabeth falls into Olson's category of an intermediate group. This is even more the case regarding smaller, close-knit business organizations such as the Afrikaanse Handelsinstituut (AHI) which has a cultural as well as a business base.

The other pressure on business to act collectively of course comes from organized labour itself. As labour is likely to be more united at a local level than at the regional level, the pressure on businesses to conform to local agreements will probably also be stronger at local level. For these reasons, then, local accords such as those negotiated in Port Elizabeth are likely to be stronger and more implementable than those negotiated in ECSECC.

\section{Conclusion}

The experience of South African business in regional social accords supports various of Olson's hypotheses concerning collective action problems. Firstly, it is difficult forging organized business - whether at national or regional level into an encompassing organization which is not weakened significantly by conflicting interests and actions on the part of redistributive coalitions. This is illustrated by the subregional rivalry between business organizations in ECSECC.

Secondly, the problem of free-riding confounds most initiatives even where the collective interest is not fragmented and is easily recognized by all parties. But as Olson suggests, this problem need not be an obstacle to action where the presence of large firms transforms organized business into a 'privileged group'. This seems to be the case with Mercedes Benz in East London. However, the very power of such large businesses can also undermine collective action in that the large business has an incentive to act unilaterally and in pursuit of its narrow interests.

Thirdly, selective social incentives can help overcome some collective action problems. As argued above, these are more 
likely to be powerful at local levels - such as in Port Elizabeth in support of local accord processes.

According to Schmitter \& Lanzalaco:

'Where identities linked to ethnicity, language use and/or religious practice combine with the strictly territorial element into a form of minoritarian-peripheral resentment, there is a much greater probability that regional corporatism will emerge and produce class compromises that mix territorial, functional and cultural objectives in a joint effort to extract advantages from the national government' (1989: 218).

While business in the Eastern Cape certainly experiences a kind of 'minoritarian-peripheral resentment'towards Gauteng, the sub regional divide between East London and Port Elizabeth business severely erodes the potential for an Eastern Cape regional corporatism to 'extract' advantages from the national government. Instead, business organizes in a fragmented way at local levels and as yet appears to offer litthe threat to South Africa's national level corporatist initiatives.

\section{Notes}

I. According to international evidence, regional associations are more important in sectors with highly protected markets, and less important in sectors more open to international competition (Van Waarden, 1989: 18).

2. In the Canadian Atlantic Provinces of Nova Scotia, New Brunswick and Prince Edward Island, maritime business interests mobilized on regional and sectoral lines in support of maintaining certain transport subsidies (Pross, 1989).

3. According to Alperson (1995) corporate social investment in South Africa tends to be lacklustre, secretive, patemalistic and often little more than an extension of corporate marketing. Those firms that reveal figures, spend between $1 \%$ and $5 \%$ of profits on social investment, and it is typically the large corporations which have the more innovative projects.

4. Recent reports about corruption and maladministration in the Eastern Cape include: the theft of R2.5 million in pension money by thieves with their own keys to the safe; the loss of cars, tools and spare parts from the Government Garage in Umtata; the defrauding of R5.3 million from the Justice Department in Lusikisiki and R4.4 million from the Health Department in Bisho; and the pilfering of government cheques for more than R31 million (The Sunday Independent, 24/11/96).

5. ECSECC's full council meets irregularly, and the bulk of the work is done by a small executive operational team. Devolving power in this way appears necessary given the large size of the full council, and the tendency for business and labour representatives to resort to 'grand-standing' tactics at such meetings.

6. Niekie Dorfling (Afrikaanse Handelsinstituut) argues that business pulled out of ECSECC not because of COSATU's actions, but rather because COSATU did not even bother to discuss the stayaway at ECSECC.

7. According to Wakeford, Port Elizabeth is the natural metropole for industrial development. The Coega site has obvious advantages (established rail and road links, 25 meter underwater draft in the harbour, 2000 available hectares, a township nearby, etc). East London business, by contrast, argue that for socio-economic reasons, development should rather take place in East
London because of the greater poverty in that region. Doubts have also been expressed about the environmental impact of the Coega development.

\section{References}

Alperson, M. 1995. Foundations for a new democracy: corporate social investment in South Africa. Johannesburg: Ravan.

Baskin, J. 1993. Corporatism: some obstacles facing the labour moygment. Johannesburg: Centre for Policy Studies, University of theWitwatersrand, Research Report 30.

Calmfors, L. \& Driffill, J. 1988. Bargaining structure, corporatism and macroeconomic performance, Economic Policy, 6: 14-47.

DBSA. 1994. South Africa's nine provinces. Halfway House: Development Bank of Southern Africa.

Douwes Dekker, L. 1988. The role of federations of unions and employers associations in negotiating the parameters of social policy. Johannesburg: Witwatersrand Business School, Research Papers, no.9.

Douwes Dekker, L. 1990. Industrial relations for a changing South Africa. Johannesburg: Lex Patria.

Eastern Cape NGO Coalition. 1996. Transkei team ignores labour and the NGOs, Poverty Profile, November. Cape Town: IDASA.

Goldberg, M. 1994. Corporatism: the South African panacea, Industrial Relations Journal of South Africa, 14(1): 6-14.

Henley, A. \& Tsakalotos, E. 1993. Corporatism and economic performance: a comparative analysis of market economies. Vermont: Edward Elgar.

Labour Market Commission. 1996. Restructuring the South African labour market. Cape Town: Labour Market Commission Report.

Maree, J. 1993. Trade unions and corporatism in South Africa, Transfurmation, 21: 24-54.

MinisPy of Finance. 1996. Growth, employment and redistribution. A macroeconomic strategy for South Africa. Pretoria: Government Position Paper, Ministry of Finance.

Naledi. 1994. Unions in transition: COSATU at the dawn of democracy. Johannesburg: NALEDI.

Nattrass, N. 1996. Business and social partnership agreements in South Africa: collective action problems and case studies. Paper prepared for the Independent Development Trust, November.

Nattrass. N. 1997. Business and employer organizations in South Africa, Occasional Report Number 5, Employment and Training Department, International Labour organization, Geneva.

NEDLAC. 1995. Discussion document on a framework for social partnership and agreement-making in NEDLAC. Johannesburg: NEDLAC.

Olson. M. 1965. The logic of collective action: public goods and the theory of groups. Cambridge: Harvard University Press.

Olson, M. 1986. A theory of the incentives facing political organisations: neo-corporatism and the hegemonic state, International Political Science Review, 7(2): 165-189.

Pross, A. 1989. Mobilising regional concern: freight rates and political learning in the Canadian Maritimes. In Coleman, W. \& Jacek, H. eds. Regionalism, business interests and public policy. London: Sage.

Schmitter, C. \& Lanzalaco, L. 1989. Regions and the organisation of business interests. In Coleman, W. \& Jacek, H. eds. Regionalism, business interests and public policy. London: Sage.

Schreiner, J. 1994. Beyond corporatism: towards new forms of public policy making in South Africa, Transformation, 23: 1-22.

Sellars, C. 1996. Interest groups and economic transition: an application of public choice theory to South Africa. Cape Town: SANER Working Paper no.l. 
Standing, G., Sender, J. \& Weeks, J. 1996. Restructuring the labour market: the South African challenge. An ILO Country Review. Geneva: International Labour Organisation.

Tolliday, S. \& Zeitlin, J. 1991. National models and internationa! variations in labour management and employer organisation. In Tolliday, S. \& Zeitlin, J. The power to manage? Employers and industrial relations in comparative historical perspective. London and New York: Routledge.

Van Waarden, F. 1989. Territorial differentiation of markets, states and business interest associations: a comparison of regional business associability in nine countries and seven economic sectors. In Coleman, W. \& Jacek, H. eds. Regionalism, business interests and public policy. London: Sage.

Windmuller, J. 1984. Employers associations in comparative perspective: organisation, structure, administration. In Windmuller, J. \& Gladstone, A. eds. Employers associations and industrial relations. Oxford: Clarendon. 